\title{
A COMPARATIVE ANALYSIS OF ON-FARM GREENHOUSE GAS EMISSIONS FROM FAMILY FARMS IN LITHUANIA
}

\author{
Vida Dabkienè \\ Lithuanian Institute of Agrarian Economics \\ vida@laei.lt
}

\begin{abstract}
The aim of paper is a comparative analysis of on-farm greenhouse gas emissions across family farm types and farm size classes using FADN data in Lithuania. To achieve this, Lithuanian FADN data of 2014 were used for the analysis. The research draws on a sample of 1304 family farms. The methodology is based on an adaptation of the IPCC guidelines using Lithuanian emission factors from Lithuania's National Inventory Report and the activity data of family farms derived from Lithuanian FADN. The GHG emissions were analysed per farm $\left(\mathrm{t} \mathrm{CO}_{2 \mathrm{eq}}\right.$ farm $\left.{ }^{-1}\right)$ and per hectare $\left(\mathrm{CO}_{2 \mathrm{eq}} \mathrm{ha}^{-1}\right.$ of UAA). The research found out that the major sources of GHG emissions are related to the use of chemical fertilizers on farms comprising $52.6 \%$ of the total emissions from family farms. The performed analysis shows that GHG emissions per farm depended on the farm size and ranged from $63.3 \mathrm{t} \mathrm{CO}_{2 \mathrm{eq}}$ farm ${ }^{-1}$ to $479.6 \mathrm{t} \mathrm{CO}_{2 \mathrm{eq}}$ farm $^{-1}$, on farm size class less than 30 ha UAA and from 500 ha UAA or over, respectively. The GHG emissions on family farms totalled $184.2 \mathrm{t} \mathrm{CO}_{2 \mathrm{eq}}$ farm $^{-1}$ and ranged from $5.8 \mathrm{t} \mathrm{CO}_{2 \mathrm{eq}}$ farm $^{-1}$ to $234.6 \mathrm{t} \mathrm{CO}_{2 \mathrm{eq}}$ farm $^{-1}$, in the permanent crops farms and in the specialist dairying farms, respectively.
\end{abstract}

Key words: GHG emissions, FADN, farming type, family farms.

\section{Introduction}

At the Paris climate conference in December 2015, 195 countries adopted the first-ever universal, legally binding global climate deal (EC, 2017). The agreement aims at holding global warming to well below 2 degrees Celsius and to 'pursue efforts' to limit it to 1.5 degrees Celsius. To accomplish this, countries have submitted Intended Nationally Determined Contributions outlining their post-2020 climate action (Rogelj et al., 2016). The European Commission in a Communication 'Roadmap for moving to a competitive low-carbon economy in 2050' has set a target to cut domestic greenhouse gas (further in text - GHG) emissions by at least $80 \%$ by 2050 compared to 1990 . According to the Intergovernmental Panel on Climate Change (further in text - IPCC) data, Agriculture, Forestry and Other Land Use sector accounts for about a quarter of net anthropogenic GHG emissions (IPCC, 2014). Therefore, it is important emitter of global emissions of GHG as agricultural sector is both a source and a sink of GHGs (Syp et al., 2015; Gocht et al., 2016). According to European Environmental Agency (further in text - EEA) data of 2014 in the structure of GHG emissions of the European Union (further in the text - EU) agriculture, the dominant sources are $\mathrm{CH}_{4}$ emissions from enteric fermentation in livestock and $\mathrm{N}_{2} \mathrm{O}$ emissions resulting from a number of processes on agricultural soils, $42.9 \%$ and $38.0 \%$, respectively. In the period of $2004-2014$ the emissions from enteric fermentation decreased by $2.4 \%$ and from agricultural soils by $1.5 \%$ in the EU.

The Common Agricultural Policy (further in text - CAP) plays an important role in achieving environmentally and climate friendly agricultural sector. In the period of 2014 - 2020 greening instruments were added to the first CAP pillar. In addition, agricultural policy encourages to implement such measures as efficient fertiliser use, bio-gasification of organic manure, improved manure management, better fodder, improved livestock productivity, local diversification and commercialisation of production, maximising the benefits of extensive farming, which are expected to reduce GHG emissions by between $42.0 \%$ and $49.0 \%$ (IEEP, 2011).

As Lynch, Donnellan \& Hanrahan (2016) noticed, GHG emissions share that arises from agricultural sector varies greatly by the EU member state. Brizga, Feng, \& Hubacek (2014) stated that Lithuania has significantly managed to reduce their total GHG emissions (from all the sectors) since the early 1990s as total GHG emissions decreased by $55.2 \%$ in 2004 . The same tendency was observed in agricultural sector, the emissions in considered period decreased by $53.7 \%$. Such results are not explained just by the adoption of the United Nations Framework Convention on Climate Change (signed in 1992) and the Kyoto Protocol (signed in 1997), but are more likely related to significant economic and political changes in Lithuania. In 2004, Lithuania became a member of the EU and Lithuanian legislation has to comply with the EU regulations and plans. According to EEA data, in 2014 as compared to 2004, the total emissions of Lithuania decreased by $9.1 \%$, though from agricultural sector it increased by $5.8 \%$. In Lithuania, emissions from agricultural sector comprised $20.1 \%$ in 2014. As compared to EU-28 agriculture sector average, it was two times higher. The enteric fermentation is responsible for $42.1 \%$ and agricultural soils for $46.4 \%$ of agricultural emissions. During the period of $2004-2014$ the emissions from enteric fermentation decreased by $1.5 \%$. On contrary, the emissions from agricultural soils increased by $18.2 \%$ in considered 
period (EEA, 2016). It should be noticed that during the period of 2004 - 2015 the number of cattle decreased by $8.8 \%$ in Lithuania (Central Statistical Office of Lithuania, 2017). Obviously this trend limits the consumption of organic fertilizers and causes higher inputs of chemical fertilizers. Vitunskienè \& Vinciūnienè (2014) calculated GHG emissions intensity indicators for the whole economy and agricultural sector in Lithuania. The research results revealed that in the period of 1995-2010 the GHG emissions intensity decreased by 2.6 times in the whole economy, whereas in agriculture, it increased by 1.4 times. Moreover, the GHG emissions intensity in Lithuanian agriculture was greater than the EU-27 average, which showed the higher GHG emissions performed per value added unit.

In line with the increased awareness of the environmental impacts from agricultural sector and the importance of farmers' decision making towards the implementation of environmentally friendly practices on farms, the GHG calculators have been developed (Hillier, 2012; Tuomisto et al., 2015). Colomb et al. (2012) assessed the developed GHG calculators for agricultural and forestry sector. The authors identified four main types of GHG calculators, those designed to raise awareness, to report, to evaluate projects and to assess products. Accordingly, the end-users of carbon calculators' tools mostly are farmers, projects evaluators and certification organizations. Though the farm-level GHG calculators are usually used at the individual farm level and are not sufficient for larger scale assessment, in order to inform decision-makers (Keller et al., 2014) and do not encourage farmers for changes as the consumers are getting more conscious about GHGs (Maraseni et al., 2010). GHG emissions assessment on farm is one of indicators measuring farms' environmental sustainability (Reidsma et al., 2015; Dillon et al., 2016). Regarding the enduser of calculator, each author tries to find the best compromise between output accuracy, data correctness and availability, user-friendliness, compatibility, transparency, and complexity (Colomb et al., 2012). Therefore, recently available databases as information sources such as the EU Farm Accountancy Data Network (further in text-FADN) have been employed for farms sustainability assessment (Longhitano et al., 2012; Dillon et al., 2016) and even calculating GHG emissions (Coderoni \& Esposti, 2014). In Lithuanian FADN the collection of information on the quantities of chemical fertilizers applied on farms was launched on 1 January 2014 under the framework of the European Council Regulation (EU) No. 1320/2013. The lack of data limited research and scientific discussion regarding fertilizers consumed and emitted GHGs on farms (Vitunskienè \& Dabkiené, 2016). In order to cover this gap, the paper's aim is a comparative analysis of on-farm greenhouse gas emissions across family farm types and farm size classes using FADN data in Lithuania.

\section{Materials and Methods}

The methodology proposed for this paper is based on an adaptation of the IPCC methodology (IPCC, 2006) using Lithuanian emission factors from Lithuania's National Inventory Report (further in the text - LNIR) (Lithuania, N. I. R., 2015) and family farms activity data derived from Lithuanian FADN. Considering the main GHG emission sources of agricultural sector and the availability of farms activity data in FADN, the emissions from enteric fermentation of domestic livestock, direct and indirect emissions from manure management and direct and indirect $\mathrm{N}_{2} \mathrm{O}$ emissions from managed soils in the study were calculated (Table 1).

The data related to manure management system on farms is not available in Lithuanian FADN. Therefore, the manure management methane emission factors for 'other system' were used for calculation. GHG

GHG emission sources accounted in the paper

Table 1

\begin{tabular}{|l|l|l|}
\hline \multicolumn{1}{|c|}{ Emission sources } & \multicolumn{1}{|c|}{ FADN activity data } & \multicolumn{1}{c|}{ Source in IPCC, 2006 } \\
\hline $\mathrm{N}_{2} \mathrm{O}$ manure management & Animal numbers & $\begin{array}{l}\text { Equation 10.25, 10.26, Annex 10A.2, Tables 10A-4 to } \\
10 \mathrm{~A}-8\end{array}$ \\
\hline $\mathrm{CH}_{4}$ manure management & Animal numbers & Equation 10.22 \\
\hline $\mathrm{CH}_{4}$ enteric fermentation & Animal numbers & Equation 10.19, 10.20 \\
\hline $\mathrm{N}_{2} \mathrm{O}$ agricultural soils & & \\
\hline Direct emissions & & \\
\hline Use of synthetic fertilizers & $\mathrm{N}$ fertilizers & Equation 11.11, Table 11.1 \\
\hline Indirect emissions & & \\
\hline Atmospheric deposition & $\mathrm{N}$ fertilizers, animal numbers & Equation 11.9, Table 11.3 \\
\hline Leaching and run-off & $\mathrm{N}$ fertilizers, animal numbers & Equation 11.10, Table 11.3 \\
\hline
\end{tabular}


emissions at different levels were calculated by summing up $\mathrm{CO}_{2}, \mathrm{CH}_{4}$ and $\mathrm{N}_{2} \mathrm{O}$ emissions based on their equivalence factor in terms of $\mathrm{CO}_{2}$ (100-year time horizon): 1 for $\mathrm{CO}_{2}, 25$ for $\mathrm{CH}_{4}$, and 298 for $\mathrm{N}_{2} \mathrm{O}$.

Lithuanian FADN data of 2014 were obtained for the analysis of GHG emissions on farms. For calculations individual farm records of 1304 family farms were used. This paper focuses on eight groups of farms depending on their production specialisation based on the EU standard classification of 'Type of Farming'. The analysis was carried out for the aftermentioned farming types: specialist cereals, oilseeds and protein crops (further in text - COP), general field cropping and mixed cropping, horticulture, various permanent crops combined, specialist dairying, grazing livestock, specialist granivores and field crops-grazing livestock combined. Alongside, the differences across farm size classes expressed in utilized agricultural area (further in the text - UAA) were estimated. As any sample of size class or farm type has to be large enough (it is advisable to present the results for a group of at least 15 farms) to comply with FADN confidentiality restrictions the number of farm size classes across farm types differs and the analysis by farm size classes for the specialist granivores, horticultural and permanent crops farms was not estimated. ANOVA test was used to measure statistical significance of the difference in the GHG emission values between the farm size classes. The coefficient of variation (further in the text $-\mathrm{CV}$ ) was calculated to CV: (SD/Mean) x 100. The statistical package for social science (SPSS 21) was employed for processing and analysis of the data.

\section{Results and Discussion}

Table 2 reports the structure of GHG emissions across farm size classes expressed in hectare of UAA.
The GHG emissions averaged 184.2 t CO$_{2 \mathrm{eq}}$ farm $^{-1}$ in Lithuanian family farms. The emitted $\mathrm{GHG}$ emissions differ significantly at six considered farm size classes. In small-sized farms, the lowest level was estimated, but in the large-sized farms - the highest level of GHG emissions, $63.3 \mathrm{t} \mathrm{CO}_{2 \mathrm{eq}}$ farm $^{-1}$ and $479.6 \mathrm{t} \mathrm{CO}_{2 \mathrm{eq}}$ farm $^{-}$ ${ }^{1}$, respectively. The major sources of $\mathrm{GHG}$ emissions are related to the use of chemical fertilizers on farms comprising $52.6 \%$ of the total emissions from family farms. The differences across considered farm size classes are significantly higher in relation to chemical fertilizers consumption on farms as compared to $\mathrm{CH}_{4}$ emissions, as the highest emissions observed were by 11.3 and 3.8 times higher in large-sized farms than in small-sized farms, respectively. It should be noted that even small reduce in chemical fertilizers consumption has positive effect on the total GHG emissions on farms because of the high $\mathrm{N}_{2} \mathrm{O}$ global warming potential. The performed analysis shows that GHG emissions per farm depend on the farm size and this finding is in consistence with some other studies (Coderoni \& Esposti, 2014).

With regard to small sample of permanent crops, horticultural and specialist granivores farms in FADN, the results of GHG emissions are presented in the average values for the total farms (Table 3). The permanent crop farms have the lowest GHG emissions with emission value of $5.8 \mathrm{t} \mathrm{CO}_{2 \mathrm{eq}}$ farm $^{-1}$. Alongside, the lowest emissions were achieved per farm area unit, i.e. $98.9 \mathrm{~kg} \mathrm{CO}_{2 \mathrm{eq}} \mathrm{ha}^{-1}$ of UAA. The value of $29.0 \mathrm{t} \mathrm{CO}_{2 \mathrm{eq}}$ farm $^{-1}$ was observed for horticultural farms and this value made $15.7 \%$ of the average value of the total farms. In terms of the emissions per area unit, horticultural farms averaged at $843.4 \mathrm{~kg} \mathrm{CO} \mathrm{CO}_{2 \mathrm{eq}} \mathrm{ha}^{-1}$ of UAA. The specialist granivores GHG emissions per farm comprised $91.6 \%$ of total emissions per family farm. The emissions per

GHG emissions structure across farm size classes (ha UAA), t $\mathrm{CO}_{2 \mathrm{eq}}$ farm $^{-1}$

\begin{tabular}{|l|c|c|c|c|c|c|c|}
\hline \multicolumn{1}{|c|}{ The GHG emission sources } & $\begin{array}{c}\text { Less than } \\
30 \text { ha }\end{array}$ & $\begin{array}{c}\text { From } 30 \text { to } \\
50 \text { ha }\end{array}$ & $\begin{array}{c}\text { From } 50 \\
\text { to } 100 \text { ha }\end{array}$ & $\begin{array}{c}\text { From } \\
100 \text { to } \\
200 \text { ha }\end{array}$ & $\begin{array}{c}\text { From } 200 \\
\text { to } 500 \text { ha }\end{array}$ & $\begin{array}{c}500 \text { ha or } \\
\text { over }\end{array}$ & Total \\
\hline $\begin{array}{l}\mathrm{CH}_{4} \text { emissions from enteric } \\
\text { fermentation and manure } \\
\text { management }\end{array}$ & 30.9 & 51.4 & 72.7 & 123.1 & 125.4 & 118.5 & 87.0 \\
\hline $\begin{array}{l}\text { Direct } \mathrm{N}_{2} \mathrm{O} \text { emissions from } \\
\text { manure management systems }\end{array}$ & 0.2 & 0.1 & 0.1 & 0.3 & 0.2 & 0.2 & 0.2 \\
\hline $\begin{array}{l}\text { Indirect } \mathrm{N}_{2} \mathrm{O} \text { emissions from } \\
\text { manure management }\end{array}$ & 0.1 & 0.0 & 0.1 & 0.2 & 0.1 & 0.1 & 0.1 \\
\hline $\begin{array}{l}\text { Direct and indirect } \mathrm{N}_{2} \mathrm{O} \text { emissions } \\
\text { from managed soils }\end{array}$ & 32.0 & 33.0 & 57.6 & 78.9 & 150.9 & 360.8 & 96.9 \\
\hline Total & 63.3 & 84.5 & 130.5 & 202.4 & 276.7 & 479.6 & 184.2 \\
\hline
\end{tabular}

Source: own calculation based on Lithuanian FADN data. 
GHG emissions of permanent crops, horticulture and specialist granivores farms

\begin{tabular}{|l|c|c|c|c|}
\hline \multicolumn{1}{|c|}{ Farm type } & Number of farms & Average farm size (ha UAA) & $\mathrm{t} \mathrm{CO}_{2 \mathrm{eq}}$ farm $^{-1}$ & $\mathrm{~kg} \mathrm{CO}_{2 \mathrm{eq}} \mathrm{ha}^{-1}$ \\
\hline Horticultural farms & 39 & 37.5 & 29.0 & 843.4 \\
\hline Permanent crop farms & 25 & 52.0 & 5.8 & 98.9 \\
\hline Specialist granivores farms & 8 & 82.5 & 168.8 & $5,082.7$ \\
\hline Total & 1,304 & 159.8 & 184.2 & $1,200.3$ \\
\hline \multicolumn{5}{|c|}{ Index (total on farms =100) } \\
\hline Horticultural farms & 3.0 & 23.5 & 15.7 & 70.3 \\
\hline Permanent crop farms & 1.9 & 32.5 & 3.1 & 8.2 \\
\hline Specialist granivores farms & 0.6 & 51.6 & 91.6 & 423.5 \\
\hline
\end{tabular}

Source: own calculation based on Lithuanian FADN data.

area unit recorded to $5,082.7 \mathrm{~kg} \mathrm{CO}_{2 \mathrm{eq}} \mathrm{ha}^{-1}$ of UAA, and it is rather obvious as livestock density is high in specialist granivores farms.

Table 4 provides average values of GHG emissions on the COP farms expressed by total emissions on farms $\left(\mathrm{t} \mathrm{CO}_{2 \mathrm{eq}}\right.$ farm $\left.^{-1}\right)$ and by an intensity indicator expressed in $\mathrm{kg} \mathrm{CO}_{2 \mathrm{eq}} \mathrm{ha}^{-1}$ of UAA. Six size classes were used to examine differences for the COP farms. GHG emissions from the use of synthetic fertilizer contributed $96.4 \%$ of the total emissions on farms. The lowest share is observed in small-sized farms whereas the largest share - in large-sized farms, $67.9 \%$ and $96.4 \%$, respectively. In addition, it shows the higher diversification of small-sized COP farm activity. The emissions of farms of 500 ha UAA or over amounted to $715.8 \mathrm{t} \mathrm{CO}_{2 \mathrm{eq}}$ farm $^{-1}$. Moreover, the GHG emission gap between the observed farm size classes is large as the lowest level of GHG emissions per farm observed on small-sized farms generated only $7.2 \mathrm{t} \mathrm{CO}_{2 \mathrm{eq}} \mathrm{farm}^{-1}$. CV value indicates much higher variation level for the total GHG emissions per farm than measuring differences among intensity values on farms $(147.5 \%$ and $32.3 \%$, respectively).

Table 5 presents the average values of the GHG emissions of the field cropping farms in identified three size classes. The GHG emissions per farm

\section{GHG emissions of COP farms by farm size classes}

\begin{tabular}{|l|c|c|c|}
\hline \multicolumn{1}{|c|}{ Farm size classes of UAA } & Number of farms & $\mathrm{t} \mathrm{CO}_{2 \mathrm{eq}} \mathrm{farm}^{-1}$ & $\mathrm{~kg} \mathrm{CO}_{2 \mathrm{eq}} \mathrm{ha}^{-1}$ \\
\hline Less than 30 ha & 39 & 7.2 & 381.7 \\
\hline From 30 to $50 \mathrm{ha}$ & 39 & 16.4 & 416.8 \\
\hline From 50 to $100 \mathrm{ha}$ & 103 & 43.8 & 599.6 \\
\hline From 100 to $200 \mathrm{ha}$ & 87 & 88.5 & 604.2 \\
\hline From 200 to $500 \mathrm{ha}$ & 126 & 240.8 & 757.7 \\
\hline 500 ha or over & 59 & 715.8 & 897.8 \\
\hline Total & 453 & 189.2 & 648.8 \\
\hline F & - & 120.3 & 9.5 \\
\hline Significance & - & $* * *$ & $* * *$ \\
\hline Coefficient of variation & - & 147.5 & 32.3 \\
\hline & Average farm size (ha UAA) & Index (total GHG on COP farms $=100)$ \\
\hline Less than 30 ha & 20.6 & 3.8 & 58.8 \\
\hline From 30 to 50 ha & 38.5 & 8.7 & 64.2 \\
\hline From 50 to 100 ha & 72.4 & 23.1 & 92.4 \\
\hline From 100 to 200 ha & 145.8 & 46.8 & 93.1 \\
\hline From 200 to 500 ha & 309.6 & 127.3 & 116.8 \\
\hline 500 ha or over & 798.7 & 378.4 & 138.4 \\
\hline
\end{tabular}

Note: $* * *$ Indicates significance at $1 \%$ level, $* *$ at $5 \%$ level, $*$ at $10 \%$ level.

Source: own calculation based on Lithuanian FADN data. 


\section{GHG emissions of field cropping farms by farm size classes}

\begin{tabular}{|c|c|c|c|}
\hline Farm size classes of UAA & Number of farms & $\mathrm{tCO}_{2 \mathrm{eq}}$ farm $^{-1}$ & $\mathrm{kgCO}_{2 \mathrm{eq}} \mathrm{ha}^{-1}$ \\
\hline Less than 50 ha & 35 & 12.9 & 487.6 \\
\hline From 50 to 200 ha & 52 & 80.1 & 744.9 \\
\hline 200 ha or over & 38 & 523.4 & $1,094.8$ \\
\hline Total & 125 & 196.0 & 779.2 \\
\hline $\mathrm{F}_{(2,122)}$ & - & 49.0 & 15.5 \\
\hline Significance & - & $* * *$ & $* * *$ \\
\hline \multirow[t]{2}{*}{ Coefficient of variation } & - & 135.0 & 39.3 \\
\hline & Average farm size (ha UAA) & \multicolumn{2}{|c|}{ Index (total GHG on field cropping farms $=100$ ) } \\
\hline Less than 50 ha & 25.7 & 6.6 & 62.6 \\
\hline From 50 to 200 ha & 101.7 & 40.9 & 95.6 \\
\hline 200 ha or over & 465.1 & 267.0 & 140.5 \\
\hline
\end{tabular}

Note: $* * *$ Indicates significance at $1 \%$ level, $* *$ at $5 \%$ level, $*$ at $10 \%$ level.

Source: own calculation based on Lithuanian FADN data.

averaged $196.0 \mathrm{t} \mathrm{CO}_{2 \mathrm{eq}}$ farm ${ }^{-1}$ and ranged from $12.9 \mathrm{t}$ $\mathrm{CO}_{2 \mathrm{eq}}$ farm $^{-1}$ to $523.4 \mathrm{t} \mathrm{CO}_{2 \mathrm{eq}}$ farm $^{-1}$, in small-sized and large sized farms, respectively. The GHG emissions related to soils management comprise $91.0 \%$ of the total emissions on farms and ranged from $73.3 \%$ in small-sized farms to $91.6 \%$ in large-sized farms. The large differences were observed in GHG emissions per farm as index values varied from $6.6 \%$ to $267.0 \%$. The same tendency of CV as in the COP farms was assessed, i.e. very large value of the $\mathrm{CV}$ in terms of emissions on farms and large in case of measuring GHG intensity per hectare of UAA, $135.0 \%$ and $39.3 \%$, respectively.

Five size classes were established for the specialist dairying farms (Table 6). The methane $\left(\mathrm{CH}_{4}\right)$ emissions from livestock farming are the dominant source of emissions in dairying and averaged $91.5 \%$. The largest share was for methane in emission structure of small-sized farms and the smallest share was observed on large-sized farms, $95.6 \%$ and $90.1 \%$,

\section{GHG emissions of specialist dairying farms by farm size classes}

\begin{tabular}{|l|c|c|c|}
\hline \multicolumn{1}{|c|}{ Farm size classes of UAA } & Number of farms & $\mathrm{t} \mathrm{CO}_{2 \mathrm{eq}}$ farm & $\mathrm{kg} \mathrm{CO}_{2 \mathrm{eq}} \mathrm{ha}^{-1}$ \\
\hline Less than $30 \mathrm{ha}$ & 64 & 32.0 & $2,386.6$ \\
\hline From 30 to $50 \mathrm{ha}$ & 57 & 83.2 & $2,025.0$ \\
\hline From 50 to $100 \mathrm{ha}$ & 74 & 148.4 & $2,021.3$ \\
\hline From 100 to 200 ha & 66 & 313.0 & $2,293.3$ \\
\hline From 200 or over & 42 & 777.6 & $2,301.4$ \\
\hline Total & 303 & 234.6 & $2,197.2$ \\
\hline F $(4,298)$ & - & 105.7 & 1.3 \\
\hline Significance & - & $* * *$ & $\mathrm{~ns}$ \\
\hline Coefficient of variation & - & 111.7 & 7.7 \\
\hline & Average farm size (ha UAA) & Index (total GHG on dairying farms=100) \\
\hline Less than 30 ha & 16.0 & 13.6 & 108.6 \\
\hline From 30 to 50 ha & 41.2 & 35.5 & 92.2 \\
\hline From 50 to 100 ha & 72.6 & 63.3 & 92.0 \\
\hline From 100 to 200 ha & 137.0 & 133.4 & 104.4 \\
\hline From 200 or over & 337.1 & 331.5 & 104.7 \\
\hline
\end{tabular}

Note: *** Indicates significance at $1 \%$ level, ** at $5 \%$ level, * at $10 \%$ level and ns (not significant)

Source: own calculation based on Lithuanian FADN data. 
GHG emissions of grazing livestock farms by farm size classes

\begin{tabular}{|l|c|c|c|}
\hline Farm size classes of UAA & Number of farms & $\mathrm{t} \mathrm{CO}_{2 \mathrm{eq}}$ farm-1 & $\mathrm{kg} \mathrm{CO}_{2 \mathrm{eq}} \mathrm{ha}^{-1}$ \\
\hline Less than 50 ha & 25 & 51.1 & $1,763.9$ \\
\hline From 50 to 100 ha & 34 & 96.1 & $1,472.3$ \\
\hline 100 ha or over & 33 & 256.7 & $1,447.0$ \\
\hline Total & 92 & 141.5 & $1,542.4$ \\
\hline $\mathrm{F}_{(2,89)}$ & - & 35.5 & 2.0 \\
\hline Significance & - & $* * *$ & $\mathrm{~ns}$ \\
\hline Coefficient of variation & - & 80.3 & 11.3 \\
\hline & Average farm size (ha UAA) & Index (total GHG on grazing livestock farms $=100)$ \\
\hline Less than 50 ha & 29.9 & 36.1 & 114.4 \\
\hline From 50 to 100 ha & 66.0 & 67.9 & 95.5 \\
\hline 100 ha or over & 175.6 & 181.4 & 93.8 \\
\hline
\end{tabular}

Note: $* * *$ Indicates significance at $1 \%$ level, $* *$ at $5 \%$ level, $*$ at $10 \%$ level and ns (not significant)

Source: own calculation based on Lithuanian FADN data

respectively. Opposite to the results gained from the COP and the field cropping farms, the large-sized dairying farms are more engaged in their activity diversification. The GHG emissions per farm differ considerably across the farm size classes, particularly between small-sized and large-size farms. The highest level of emissions per farm was achieved on farm size class of 200 ha UAA or over and this was 3.3 times more than average emissions on dairy farms whereas the differences across farm size classes in terms of GHG emissions per unit area (expressed as emissions per hectare of UAA) were not significant and minor. This is evidenced by low calculated $\mathrm{CV}$ value which equalled to $7.7 \%$.
Table 7 summarizes the results of the GHG emissions on grazing livestock farms in examined three size classes. The methane $\left(\mathrm{CH}_{4}\right)$ emissions from livestock farming are the dominant source of emission in grazing livestock farms the same as in dairying farms and averaged $95.4 \%$ ranging from $97.0 \%$ and $95.4 \%$, in size class less than 50 ha UAA and from 100 ha UAA or over, respectively. The total emissions per farm differ considerably by farm size classes as $\mathrm{CV}$ equalled $80.3 \%$ whereas the differences of emissions values expressed as intensity indicator $\mathrm{kg} \mathrm{CO}_{2 \mathrm{eq}}$ ha $^{-1}$ of UAA were moderate (CV value was $11.3 \%$ ) and were not statistically significant.

Table 8

GHG emissions of field crops-grazing livestock combined farms by farm size classes

\begin{tabular}{|l|c|c|c|}
\hline Farm size classes of UAA & Number of farms & $\mathrm{t} \mathrm{CO}_{2 \mathrm{eq}} \mathrm{farm}^{-1}$ & $\mathrm{~kg} \mathrm{CO}_{2 \mathrm{eq}} \mathrm{ha}^{-1}$ \\
\hline Less than 50 ha & 61 & 26.9 & 964.8 \\
\hline From 50 to 200 ha & 99 & 130.8 & $1,186.6$ \\
\hline 200 ha or over & 49 & 504.3 & $1,496.3$ \\
\hline Total & 209 & 188.1 & $1,194.5$ \\
\hline $\mathrm{F}_{(2,206)}$ & - & 161.4 & $* * *$ \\
\hline Significance & - & $* * *$ & 22.0 \\
\hline Coefficient of variation & Average farm size (ha UAA) & Index (total GHG on field crops-grazing livestock \\
\hline & 29.6 & 113.8 & 80.8 \\
\hline Less than 50 ha & 104.1 & 69.5 & 99.3 \\
\hline From 50 to 200 ha & 332.4 & 268.1 & 125.3 \\
\hline 200 ha or over & & & \multicolumn{2}{|c|}{} \\
\hline
\end{tabular}

Note: $* * *$ Indicates significance at $1 \%$ level, $* *$ at $5 \%$ level, $*$ at $10 \%$ level.

Source: own calculation based on Lithuanian FADN data. 
The average GHG emission values per farm and per area unit across three established farm size classes for field crops-grazing livestock combined farms are presented in Table 8 . The methane emissions in these farms averaged $72.1 \%$, and the lowest share was established on small-sized farms (less than 50 ha UAA).

Farms of 200 ha UAA or over were the biggest source of GHG emissions both in terms of emissions per farm and per area unit. The gap between farm size class less than 50 ha UAA and from 200 ha UAA or over is large, as the emissions in the largest size farm class were 18.7 times higher than in small-sized farms class. Additionally, the CV value of about $113.8 \%$ indicated very large differences regarding emissions per farm. The variation of GHG emissions per unit area $\left(\mathrm{kg} \mathrm{CO}_{2 \mathrm{eq}} \mathrm{ha}^{-1}\right)$ was found significant among different farm size classes with $\mathrm{CV}$ value of $22.0 \%$.

\section{Conclusions}

1. The assessment of GHG emissions on farms revealed that:

- major sources of GHG emissions are related to the use of chemical fertilizers on farms comprising $52.6 \%$ of the total emissions from family farms. Therefore, chemical fertilizer application planning on farms should be taken into account in achieving environmentally and climate friendly agricultural sector;

- the GHG emissions on farms averaged $184.2 \mathrm{t}$ $\mathrm{CO}_{2 \mathrm{eq}}$ farm $^{-1}$ and ranged from $5.8 \mathrm{t} \mathrm{CO}_{2 \mathrm{eq}}$ farm $^{-1}$ to $234.6 \mathrm{t} \mathrm{CO}_{2 \mathrm{eq}}$ farm $^{-1}$, on the permanent crop farms and on the specialist dairying farms, respectively;

- the GHG emissions differ significantly across farm size classes. In small-sized farms, the lowest level was estimated, but in the largesized farms - the highest level of the GHG emissions, 63.3 t $\mathrm{CO}_{2 \mathrm{eq}}$ farm $^{-1}$ and $479.6 \mathrm{t} \mathrm{CO}_{2 \mathrm{eq}}$ farm $^{-1}$, respectively;

- the GHG emissions intensity averaged 1,200.3 $\mathrm{kg} \mathrm{CO}_{2 \mathrm{eq}} \mathrm{ha}^{-1}$ of UAA on family farms and varied from $98.9 \mathrm{~kg} \mathrm{CO} \mathrm{CO}_{2 \mathrm{eq}} \mathrm{ha}^{-1}$ of UAA to $5,082.7 \mathrm{~kg} \mathrm{CO}_{2 \mathrm{eq}} \mathrm{ha}^{-1}$ of UAA on the permanent crop farms and on specialist granivores farms, respectively.

2. The GHG assessment across different farming types and farm size classes provides insights for farmers and policy makers about the source and magnitude of GHG emissions in the agricultural sector. Alongside, the indicator related to the $\mathrm{GHG}$ emissions on farm can contribute to the continued development of sustainability assessment tool at a farm level.

\section{References}

1. Brizga, J., Feng, K., \& Hubacek, K. (2014). Drivers of greenhouse gas emissions in the Baltic States: A structural decomposition analysis. EcologicalEconomics, 98,22-28. DOI: 10.1016/j.ecolecon.2013.12.001.

2. Central Statistical Office of Lithuania. (2017). Retrieved March 2, 2017, from: http://osp.stat.gov.lt/en/ temines-lenteles57.

3. Coderoni, S., \& Esposti, R. (2014). The evolution of agricultural GHG emissions in Italy and the role of the CAP A farm-level assessment. In 2014 Third Congress, June 25 - 27, 2014 (pp. 1 - 18). Alghero, Italy (No. 173012). Italian Association of Agricultural and Applied Economics (AIEAA).

4. Colomb, V., Bernoux, M., Bockel, L., Chotte, J.L., Martin, S., Martin-Phipps, C., ... Touchemoulin, O. (2012). Review of GHG calculators in agriculture and forestry sectors. A Guideline for Appropriate Choice and Use of Landscape Based.

5. Dillon, J.E., Hennessy, T., Buckley, C., Donnellan, T., Hanrahan, K., Moran, B., \& Ryan, M. (2016). Measuring progress in agricultural sustainability to support policy-making. International Journal of Agricultural Sustainability, 14(1), 31 - 44. DOI: 10.1080/14735903.2015.1012413.

6. EC. (2017). Paris Agreement. Retrieved March 2, 2017, from: https:/ec.europa.eu/clima/policies/ international/negotiations/paris_en.

7. EEA. (2016). EEA Greenhouse Gas - Data Viewer. Retrieved March 2, 2017, from: http://www.eea. europa.eu/data-and-maps/data/data-viewers/greenhouse-gases-viewer.

8. Gocht, A., Espinosa, M., Leip, A., Lugato, E., Schroeder, L.A., Van Doorslaer, B., \& y Paloma, S.G. (2016). A grassland strategy for farming systems in Europe to mitigate GHG emissions - An integrated spatially differentiated modelling approach. Land Use Policy, 58, 318 - 334.

9. Hillier, J. (2012). Cool farm tool. University of Aberdeen: Aberdeen, UK.

10. IEEP. (2011). New EU Roadmap for a Competitive Low Carbon Economy Calls Agriculture and Land Management to Action. Retrieved March 2, 2017, from: http://cap2020.ieep.eu/2011/3/31/new-euroadmap-for-a-competitive-low-carbon-economy-calls-agriculture-and-land-management-to-action.

11. IPCC. (2006). IPCC guidelines for national greenhouse gas inventories. Retrieved March 2, 2017, from: http://www.ipcc-nggip.iges.or.jp/public/2006gl/vol4.html. 
12. IPCC. (2014). Climate Change 2014: Impacts, Adaptation, and Vulnerability. Part A: Global and Sectoral Aspects. Contribution of Working Group II to the Fifth Assessment Report of the Intergovernmental Panel on Climate Change. Cambridge University Press, Cambridge, United Kingdom and New York, NY, USA.

13. Keller, E., Chin, M., Chorkulak, V., Clift, R., Faber, Y., Lee, J., ... Viart, N. (2014). Footprinting farms: a comparison of three GHG calculators. Greenhouse Gas Measurement and Management, 4(2 - 4), 90 - 123. DOI: $10.1080 / 20430779.2014 .984609$.

14. Lithuania, N.I.R. (2015). 2015 Greenhouse Gas Emissions 1990-2013. Retrieved March 2, 2017, from: http://klimatas.gamta.lt/files/LT\%20NIR\%202015.pdf.

15. Longhitano, D., Bodini, A., Povellato, A., \& Scardera, A. (2012). Assessing farm sustainability. An application with the Italian FADN sample. In 1st AIEAA Conference 'Towards a Sustainable Bio-economy: Economic Issues and Policy Challenges (pp. $4-5$ ).

16. Lynch, J., Donnellan, T., \& Hanrahan, K. (2016). Exploring the Implications of GHG Reduction Targets for Agriculture in the United Kingdom and Ireland. In 90th Annual Conference, April 4 - 6, 2016, Warwick University, Coventry, UK (No. 236370). Agricultural Economics Society.

17. Maraseni, T.N., Cockfield, G., Maroulis, J., \& Chen, G. (2010). An assessment of greenhouse gas emissions from the Australian vegetables industry. Journal of Environmental Science and Health Part B, 45(6), 578 - 588. DOI: 10.1080/03601234.2010.493497.

18. Reidsma, P., Bakker, M.M., Kanellopoulos, A., Alam, S.J., Paas, W., Kros, J., ... de Vries, W. (2015). Sustainable agricultural development in a rural area in the Netherlands? Assessing impacts of climate and socio-economic change at farm and landscape level. Agricultural Systems, 141, 160 - 173. DOI: 10.1016/j. agsy.2015.10.009.

19. Rogelj, J., Den Elzen, M., Höhne, N., Fransen, T., Fekete, H., Winkler, H., ... \& Meinshausen, M. (2016). Paris Agreement climate proposals need a boost to keep warming well below 2 C. Nature, 534(7609), 631 - 639. DOI: 10.1038/nature18307.

20. Syp, A., Faber, A., Borzęcka-Walker, M., \& Osuch, D. (2015). Assessment of Greenhouse Gas Emissions in Winter Wheat Farms Using Data Envelopment Analysis Approach. Polish Journal of Environmental Studies, 24(5), 2197 - 2203. DOI: 10.15244/pjoes/39682.

21. Tuomisto, H.L., De Camillis, C., Leip, A., Nisini, L., Pelletier, N., \& Haastrup, P. (2015). Development and testing of a European Union-wide farm-level carbon calculator. Integrated environmental assessment and management, 11(3), 404 - 416. DOI: 10.1002/ieam.1629.

22. Vitunskiene, V., \& Dabkiene, V. (2016). Framework for assessing the farm relative sustainability: a Lithuanian case study. Agric. Econ.-Czech, 62. 134 - 138. DOI: 10.17221/125/2015-AGRICECON.

23. Vitunskienė, V., \& Vinciūnienè, V. (2014). Viešosios paramos reikšmé siekiant aplinkos darnumo Lietuvos žemès ūkyje (The importance of public support in achieving agri-environmental sustainability in Lithuania). From: Sustainable development: theory and practice: collective monograph. (pp. 252 - 281). Vilnius (in Lithuanian). 